\title{
Factors affecting Attitudes and Behavior of Greek Secondary School Students on Current Environmental Issues
}

\author{
Myrto GANATSA ${ }^{1}$ \\ Aristotle University, Thessaloniki, GREECE
}

\author{
Marianthi TSAKALDIMI ${ }^{2}$ \\ Aristotle University, Thessaloniki, GREECE
}

\author{
Petros GANATSAS ${ }^{3}$ \\ Aristotle University, Thessaloniki, GREECE
}

\begin{abstract}
1; Aristotle University, P.O. Box 262, University Campus, GR 54124, Thessaloniki,GREECE. myrtoganatsa [at] gmail.com.ORCID: 0000-0002-8590-1494

${ }^{2}$ Corresponding author:Assist. Prof. Dr.;Aristotle University, Department of Forestry and Natural Environment, P.O. Box 262, University Campus, GR 54124, Thessaloniki, GREECE. marian [at]for.auth.gr.ORCID:0000-0003-4202-6404

${ }^{3}$ Prof. Dr.; Aristotle University, Department of Forestry and Natural Environment, P.O. Box 262, University Campus, GR 54124, Thessaloniki,GREECE. pgana [at] for.auth.gr.ORCID: 0000-0002-9613-3072
\end{abstract}

\begin{abstract}
Although, Greece is a Mediterranean country where, particular regions of its territory threatened with substantial impacts due to climate change, the academic research and critical reflection on the effects of the environmental and sustainability education initiative are lacking. Several studies, in Greece and worldwide, have been conducted on school students' perceptions, ideas and understanding current environmental issues: climate change, greenhouse effect, and global warming. However, this study is the first that examines how students' environmental knowledge, attitude and behavior develop throughout adolescence and investigates the interaction between students' cognitive level and the Greek official secondary school curriculum. A total of 600 secondary students participated, answering a questionnaire that focused on the students' cognitive level on the environmental issues in relation to the official school curriculum, the influence of socio-demographic characteristics (students' age, gender, school district, parents' educational level), their environmental knowledge and consciousness, the information sources in the construction of their knowledge and awareness, as well as their suggestions for mitigation the environmental problems and finally the school vital role in informing and raising awareness.
\end{abstract}

\section{Keywords}

Greek Secondary School Students; Education; Environmental Consciousness; Curriculum; Cognitive Level 
Greenhouse effect, global warming and their impacts on climate change are currently among the most important environmental problems on the planet (Schreiner et al., 2005; Bozdogan, 2011; Bolaji and Huan, 2013; Varela et al., 2020). A lot of research was dedicated in the linkages of increasing greenhouse gases and global warming with their combined effect on global climatic change (National Research Council, 1989). The Intergovernmental Panel on Climate Change (IPCC, 2014) announced that global warming is unequivocal and a series of unprecedented changes have been observed since the 1950s. Man's action is clear and unquestionable in the rapid increase in climate change occurred in recent decades and its effects may last for centuries.

Alarming trends regarding greenhouse effect, changes in the atmosphere's composition, global warming and climate change, are urgent issues of discussion and study among scientists, politicians, teachers and public. Several studies in the education have concentrated on students' conceptualization of these topics along the world (Hansen, 2010; Bozdogan, 2011; Arslan et al., 2012; Varela et al., 2020).

Without a firmer grasp of human attitude and behavior towards environmental issues, the difficult challenge of global climate change cannot be addressed (Otto et al., 2019). A decisive factor in mitigating these urgent environmental problems is the "environmental consciousness" of the community. Education could play a vital role in forming such an environmental consciousness in the community, by providing knowledge and shape such attitudes and behaviors of students, which in turn could contribute to the protection and improvement of the quality of the environment (Ozmen and Karamustafaoğlu, 2006; Stevenson, 2007; Jickling and Wals, 2008; Zsoka et al., 2013; Braun et al., 2018). This can be mainly achieved through teaching relevant courses in "natural sciences" during the primary and secondary school period of education.

According to Hines et al. (1987), environmental consciousness of the individual is affected by four sets of factors: socio-demographic (age, sex and level of education), cognitive level (environmental knowledge), environmental intervention (information on what can be done to change behavior) and psychosocial (one's own responsibility on their actions). The participation of the students in the implementation of relevant environmental education projects, within schools' programs, could also provide additional chances (Liarakou et al. 2011, Sanchez-Llorens et al., 2019).

Although the subject of climate change is one of the most important social-scientific issues, numerous studies have shown that students' ideas about climate change are still inadequate (Varela et al., 2020). Similarly, in a study of Shepardson et al. (2009) who reviewed 16 international studies concerning secondary students' conceptions of global warming and climate change, they concluded that most students do not distinguish the types of greenhouse gases involved in the greenhouse effect, and they also confuse the ozone hole with the greenhouse effect. In fact, these environmental phenomena are relative complex and students express different and sometimes wrong conceptions and experience difficulties even after educational interventions (Daniel et al., 2004; Lee et al., 2007). Other educational studies on such environmental issues concluded that the knowledge and capabilities required understanding them, are not easy to acquire. Thus, there is a need for a new learning process, contrary to the traditional fragmented 
curricula, through which can be approached in an integrated way, i.e. in an interdisciplinary, systemic and holistic view (Liarakou et al., 2011).

In Greece, a Mediterranean country which is identified as one of the main "hotspots" of climate change projections, demonstrating increases in temperature and evapotranspiration, reductions in precipitation and runoff, and a prolongation of dry summer periods (Mimikou and Baltas, 2013; Eleftheriou et al., 2018; Van der Schriek, et al., 2020), little research has so far dealt with the environmental consciousness and the adolescents' conceptions and behavior concerning the above-mentioned environmental issues (Boyes et al., 1999; Papageorgiou and Tsiropoulou, 2004; Liarakou et al., 2011). Additionally, there is a great lack of knowledge in Education science, on the interaction between students' cognitive level and the official secondary school curriculum, regarding urgent environmental issues as: climate change, greenhouse effect, global warming etc.

Thus, it would be of great interest to be informed about the Greek children's or young people's knowledge and consciousness about the environment, if they have incomplete or erroneous understanding and habits about it, given that the environmental education in Greek schools is identified with the implementation of corresponding projects and its value is marginalized through the official school curriculum. In secondary schools, these projects takes place in hours outside the program schedule and participation in them is optional for both teachers and students.

This study is the first that conducted to examine in depth how students' environmental knowledge and behavior develop throughout adolescence (ages 13 to 16) and to investigate the interaction between students' cognitive level and the official secondary school curriculum. Adolescence, the period of students' high psychosomatic development, greatly affects the development of students' personality, and shapes their attitudes and behaviors towards environment protection. Several researchers have concluded that adolescents (13-17 year-olds) have less interest in and concern about environmental issues, despite their importance for their future, than younger and older students (Olsson \& Gericke, 2016). In the present study, the adolescents' changing behavior was examined both from their specific actions and from their replacing old habits (Braun et. al., 2018). However, differences in the knowledge, attitudes, and behaviors toward environmental issues may also be different in adolescents from different socio-demographic level (e.g. urban schools vs rural, males vs females etc. Thus, in order to achieve the above, the current study tried to investigate the following arising issues:

a) whether Greek high school students (7th, 8th, 9th grade) have understood the environmental terms "greenhouse effect", "global warming", what human activities cause them, and what are the impacts on the natural environment and people's health,

b) how the socio-demographic characteristics of students (grade of attendance, gender, school district, level of education of parents) affect students' cognitive level on the above mentioned environmental issues?

c) to what extent students' cognitive level is related to the official curriculum of secondary school concerning the above issues? (after a detailed research of the courses taught and the relevant chapters), 
d) whether the gained knowledge affects their consciousness and daily behavior in relation to the environment as well as their suggestions for mitigation these environmental problems,

e) what are the information sources and what is their contribution in the construction of knowledge and awareness of the students for the above mentioned issues and what the importance of school's role?

\section{Methodology}

\section{Sampling and Research Tool}

In order to respond to our research aims, a questionnaire was prepared as a research tool to record and analyse students' conceptions (Olsson et al. 2019). A number of 600 questionnaires were given to high-school students (age 13-16) in four schools of northern Greece, approx. two months after the beginning of the school year (November 2017-2018). The almost semi- structured questionnaire consisted of 15 questions, 14 in multiple-choice format and one open-ended. The questions divided in six sub-axes, as follows: i) "Students' cognitive level" namely students' knowledge on the interpretation of the terms "greenhouse effect" and "global warming", what human activities affect them, and their impacts on the natural environment and people's health, ii) students' actions and behaviour in their daily life regarding these environmental issues, namely "students consciousness", iii) the sources of students' information on the examined issues, iv) personal students' suggestions for mitigation the above environmental problems; v) students' opinion on how sufficient the relevant information provided by the school is, and vi) whether the students consider necessary the school to provide them with such knowledge.

Most of the questions were in multiple choice format, therefore, a binary system of "true" and "false" was adopted (in order to fit effective statistical processing), so that one correct answer is taken as "true" and the others as "false". Three questions as: q-4: Is human health in danger because of the greenhouse effect?, q-14 : Do you believe that your knowledge is sufficient to answer the questionnaire correctly? and q-15: Do you consider necessary your school provide appropriate further knowledge on these issues?, could be answered with "YES" or "NO". Only in one question, in q-10: Suggest a solution, the most important for the mitigation of the above-mentioned environmental issues, the students could freely express their opinion.

The questionnaire included socio-demographic data of students: gender (male/female), age (7th, 8th and 9th grade of attendance), education level of their parents (primary/secondary/higher) and school district. The research was conducted in four public high schools distributed in four districts of northern Greece that present many differences in their socio-geographic characteristics: a) the 1st high school of Trilofos, b) the 2nd high school of Evosmos, c) the high school of Pefka, and d) the high school of Aiginio. The first three schools (Trilofos, Evosmos, Pefka) are located in the metropolitan area of Thessaloniki city, and the last one (high school of Aiginio) in the Pieria regional unit. Analytically, the socio-geographic characteristics of the high schools districts are depicted in Table 1 and Figure 1a, b. 
Ganatsa, M.; Tsakaldimi, M.; Ganatsas, P. (2021).Factors affecting attitudes and behavior of Greek...

Table 1

Main Socio-Geographic Characteristics of the Four (4) High Schools' Districts of Northern Greece

\begin{tabular}{|c|c|c|c|c|}
\hline $\begin{array}{l}\text { Name of the } \\
\text { high school } \\
\text { district }\end{array}$ & Type of area & $\begin{array}{l}\text { Altitude } \\
\text { (m) }\end{array}$ & Population* & $\begin{array}{l}\text { Population } \\
\text { density } \\
\text { (inhabitants/ } \\
\mathrm{km}^{2} \text { ) }\end{array}$ \\
\hline Trilofos & $\begin{array}{l}\text { Rural hilly area, village, a place } \\
\text { of permanent urban residence } \\
\text { (during last decade) }\end{array}$ & 120 & 7,405 & 0.21 \\
\hline Evosmos & $\begin{array}{l}\text { Urban densely-populated area } \\
\text { with smooth terrain }\end{array}$ & 35 & 74,686 & 7.52 \\
\hline Pefka & $\begin{array}{l}\text { Suburb of Thessaloniki, a place } \\
\text { of permanent urban residence } \\
\text { (during last decade), hilly } \\
\text { terrain }\end{array}$ & 280 & 13,052 & 7.25 \\
\hline Aiginio & $\begin{array}{l}\text { Rural area, small Town, hilly } \\
\text { terrain }\end{array}$ & 30 & 4,345 & 0.07 \\
\hline
\end{tabular}

\section{Procedure of Data Collection and Statistical Analysis}

The questionnaires were distributed to the students by the teachers who explained them the aim of the study, gave them the necessary instructions and clarified that the completion of the questionnaire was voluntary and anonymous. All the questionnaires were completed in the classroom under supervision of the teacher, without any time restriction. There were no missing values in questionnaires.

To evaluate the differences in students' cognitive level and students' consciousness between the socio-demographic variables, non-parametric testing was considered because even after data transformations, with the aim of achieving normality, the distribution of the students' cognitive level and students' consciousness, remained non-normal (Shapiro-Wilk test). Thus, non-parametric Mann-Whitney $U$ test was performed for variable with two categories (gender), and Kruskal-Wallis test for variables with more than two categories (grade of attendance, parents' education level, school district), (Ablak \&Yeşiltaş 2020).

For both tests, all assumptions were met, in particular, the assumption of "homogeneity of variance between the groups." Results were considered statistically significant at $p<.05$. Analyses were performed using SPSS (SPSS ${ }^{\circledR} 23.0$ ), (Tzimpoulas et al., 2019). All the questions made, and the results obtained are depicted graphically in Map 1-a,b and in Table 2, except for the answers to questions 14 (q 14) and 15 (q 15). Percentages were used to display the data. 


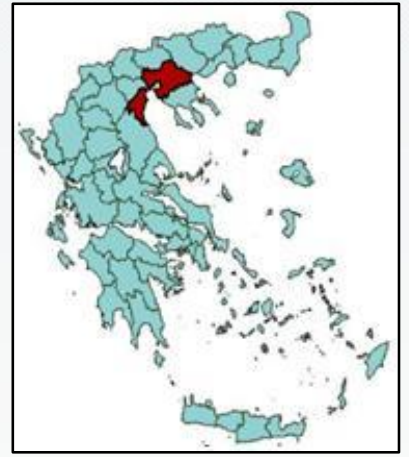

a

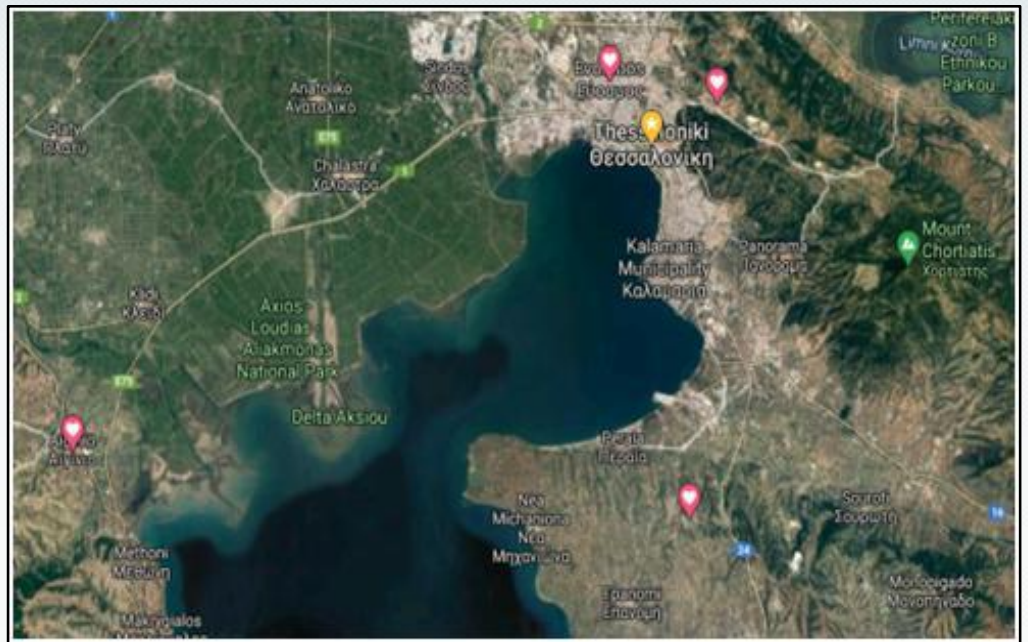

b

Map 1a,b: Map of Greece depicting the studied regional units (a), the four districts of northern Greece (Trilofos, Evosmos, Pefka, Aiginio) where the studied high schools are located (b).

\section{Results and Discussion}

\section{Students' Cognitive Level In Relation To the Official Curriculum of Secondary School}

The results' analysis shows that students' cognitive level on examined environmental issues is quite high as, except for question 8, a significant percentage of students answered correctly ( $>50 \%$ ), while in most cases this percentage was ranged between 65 to $95 \%$ (Figures 1-4). The large percentages of correct answers, especially to the question 2:"What human activities contribute to greenhouse effect and global warming", clearly show that students' awareness of human actions intensifying environmental problems is high. Similarly, an earlier study conducted in Greek high schools (Liarakou et al. 2011), found a general improvement in students' knowledge on climate change due to their educational level.

The secondary school curricula of many countries, including Greece, have already incorporated environmental issues such as greenhouse effect, global warming and climate change. In the detailed curriculum of the three grades of Greek high school, after a careful search, the students are taught about greenhouse effect and global warming as follows: in 7th \& 8th grade Home-Economics textbook (Ampeliotis et al., 2015), the section: "Ecological crisis" contains information on greenhouse effect, but from 2016 to 2018 when this research was conducted, this subject was not taught in high school, that is, the students in this study were not taught it. In 8th \& 9th grade's Biology textbook (Mavrikaki et. al., 2016), the section: "Human interventions to the environment" contains information on greenhouse effect and global warming. In 8th grade Chemistry (Avramiotis et al., 2015) in the section "Carbon Dioxide", the greenhouse effect is analyzed and there is a simple reference on global warming. In 9th grade Chemistry (Theodoropoulos et al., 2016) in the section "Hydrocarbons", it is referred that "the carbon dioxide is a gas of greenhouse and is responsible for global warming". Additionally, in 7th grade Geology-Geography text book (Pavlopoulos \& Galani, 2016) in the section "Natural Resources", it is referred that "by the combustion 
of fossil fuels, like carbon, are released gasses (e.g. carbon dioxide) that pollute the atmosphere and aggravate the greenhouse effect".

According to the above curriculum analysis, the high percentage of correct answers of 8th and 9th grade students (age $14 \& 15$ ) (Figure 1) can mainly be attributed to the course of Biology with an enrichment of relevant knowledge they received from other courses. Also, quite a large percentage of 7 th grade students $(>50 \%)$ gave correct answers, although their correct answers are not justified by the curriculum either from the primary school or the high school, and it could be attributed to other sources. According to the Greek primary school curriculum, and the relevant official teaching instructions from the Ministry of Education, from the year 2010 onwards, there is no mandatory teaching of the above mentioned environmental issues, although in the chapter "The atmosphere" in the 6th Grade Geography's textbook (Koutsopoulos et al., 2016) there is a small text dedicated to greenhouse effect and a reference on global warming. It is only the teacher's willingness to teach that issues in the context of environmental exercises of the courses "Environmental Studies" and "Geography". Due to the importance of these problems for our planet, many teachers take care to inform the students about it and/or the students get enough information from the family, the wider social environment and the various communication media. In any case, the teachers' role seems very important and teachers' education is therefore crucial (Ekborg and Areskoug, 2006; Nyberg et al., 2020).

\section{The Effect of Age (Grade of Attendance), and Gender on Students' Cognitive Level}

There is an evident trend of increase of correct answers from 7th to 9th grade students in most questions (Figure 1) which is probably due to the students' greater maturity or due to their knowledge acquired from the taught courses. The difficulty of students to answer correctly in question 8: "Put the following means of transport (car, bicycle, group car use, bus) in ascending order based on their carbon dioxide emissions" could be probably due to question structure; students may know which transport means emit carbon dioxide and which do not, but to put them in the right order, requires more specialized knowledge and understanding, which they acquire at older ages. Thus, the 9 th grade students gave statistically significantly higher percentage of correct answers in this question $(\mathrm{p}<.05)$.

Among the 303 boys and 297 girls that participated in this research, the statistical analysis did not show statistically significant differences $(p>.05)$ in the correct answers between male and female students (Figure 2). This finding is in agreement with those from previous research works conducted to study cognitive gender differences within school students (Hyde and McKinley, 1997; Carrier, 2010), and it strengthens the view that there are no significant gender differences in ability to acquire the environmental knowledge.

\section{The Effect of School District and Parents' Educational Level on Students' Cognitive Level}

No significant differences ( $p>.05)$ were detected between urban and rural students concerning the relevant environmental knowledge (Figure 3). It should be noted that except for the questions concerning global warming (q-11 and q-12), in which the school of Pefka seems to be clearly superior, in all other questions, the performance of 
all the studied schools is similar. In the same line with our findings, Worsley and Skrzypiec (1998) found no significant differences between metropolitan and rural secondary students in their environmental attitudes. Similarly, students of different regions of Tehran did not show significant difference in cognitive scores about global warming (Yazdanparast et al., 2013).

Parents' educational level does influence the percentage of correct answers significantly $(\mathrm{p}<.05)$, (Figure 4$)$. This percentage found lower to students who their parents received only primary education. We have to point out that only $1.6 \%$ of students responded that their parents finished the primary school, while $69.1 \%$ said that their parents have received higher education. Similarly, Azadani et al. (2013) found that secondary school students' environmental knowledge and awareness were affected by the educational level of students' parents.

\section{The Effect of Socio-Demographic Characteristics of Students on Their Environmental Consciousness}

The results are not so encouraging regarding the students' actions and behavior in their routine life, in relation to what they learn about the examined environmental issues (Figures 5-7). It seems, as other scientists also conclude, that knowledge cannot be interpreted as the guaranteed determinant for environmental behavior (Braun et al. 2018). High school students seem to have some difficulties in applying what they know in practice, even though they have a very good knowledge on them. Regardless gender, grade of attendance and school district, a percentage of $59.3 \%$ of students prefers to wear an extra cloth (e.g. jacket) instead of turning up house heating (q-5), or to adjust house temperature at around $20 \mathrm{oC}(\mathrm{q}-7)(55 \%)$, and to go to school on foot or by bike (q-9) (49.2\%). According to our study, no significant differences were detected in students' environmental consciousness and daily behavior in relation to their age, although a downward trend was observed with the grade of attendance, with 7th grade students to present a greater environmental consciousness (Figure 5). That is, an opposite trend was observed compared to the cognitive level. Otto et al. (2019) also observed an age trend for students' environmental attitude and behavior, which seems to be a curvilinear pattern; starting to increase to the ages of about 10-12 and then decreasing again until young adulthood.

Generally the students' gender did not significantly influence their awareness and behavior. However, an interesting point is the significantly larger $(\mathrm{p}<.05)$ willingness of girls to go to school on foot (75\%) than boys (55\%), (Figure 6). How students' gender and age affect the relationship between their environmental knowledge, attitudes, and behavior was of interest to several researchers. Ablak \& Yeşiltaş (2020) concluded that the gender does not make any significant difference in secondary school students' awareness about environmental education. Loughland et al. (2003), who studied gender responses from students' ages 9- 17 in order to determine if they saw the environment as an "object" or as "relation", found that girls saw the environment as a "relation" more than boys. The study of Leslie et al. (2010) showed that while more girls $(44.3 \%)$ than boys (37.4\%) (6-8 years old) walked to school, lower proportions of girls rode bikes $(8.3 \%$ vs $22.4 \%)$ and hence fewer were active travelers overall. Coyle (2004) also, concluded that females show more concern for the environment in general (over economy, air and water quality, support laws for endangered species protection and natural areas) and had higher expectations for environmental education than males. 
Ganatsa, M.; Tsakaldimi, M.; Ganatsas, P. (2021).Factors affecting attitudes and behavior of Greek...
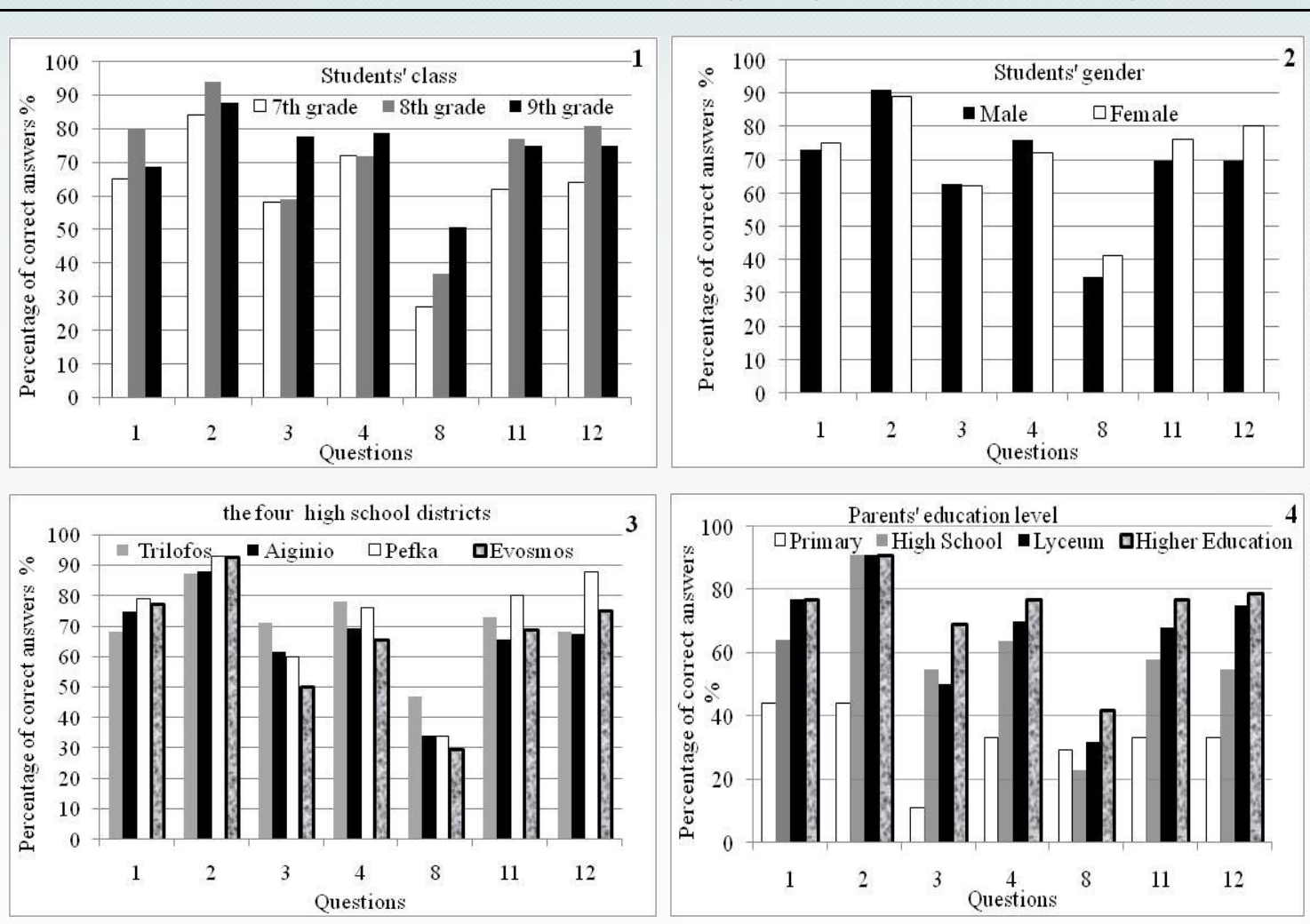

Figures 1-4. Students' cognitive level in relation to their age (grade of attendance) (1), gender (2), school district (3) and education level of parents (4). Bars depict students' percentages that answered correctly to the following questions $(\mathrm{q})$ :

$\mathrm{q}-1$ : What is the greenhouse effect?

q-2: What human activities contribute to greenhouse effect and global warming?

q-3: Which gas does not aggravate greenhouse effect?

q-4: Is human health in danger because of the greenhouse effect?

q-8: Put the following means of transport (car, bicycle, group car use, bus) in ascending order based on their carbon dioxide emissions,

q-11: What is global warming?

q-12: How can global warming threaten human health?

Students from the Evosmos district (urban area) choose to go to school on foot in a very large percentage $(90 \%)$, which is significantly higher $(\mathrm{p}<.05)$ than the other schools' (40-50\%), (Figure 7). This difference is possibly attributed to the fact that Evosmos is a densely populated urban area with smooth terrain, where students' houses are located nearby the school and the public transport can efficiently serve all students. The other studied areas (Trilofos, Pefka and Aiginio; rural, suburban and rural area respectively) are either quite spread out or the public transport cannot serve all students, resulting in many parents being forced to take their children to school by car. In case of Trilofos village, its terrain characterized by quite high slopes (as shown by its name 'Trilofos' = three hills), which makes it difficult to use bikes. However, the influences on the students' choice to walk or cycle to school are so complex and include a range of personal, social and environmental factors such as cultural norms, good transport means, safe traffic conditions, and distance from the school and terrain morphology. An interesting point is the significantly $(\mathrm{p}<.05)$ larger choice $(70 \%)$ of Trilofos' high school students to wear an extra cloth rather than raising the heating temperature. This is 
probably due to the higher cost of heating of the large houses (maisonettes) located in this village. Also, the majority of students (around 80\%) choose to turn off the heating when they open the windows to get fresh air, while significantly different behavior $(p<.05)$ was observed by the students from Aiginio, that only the $60 \%$ do that (Figure $7)$.
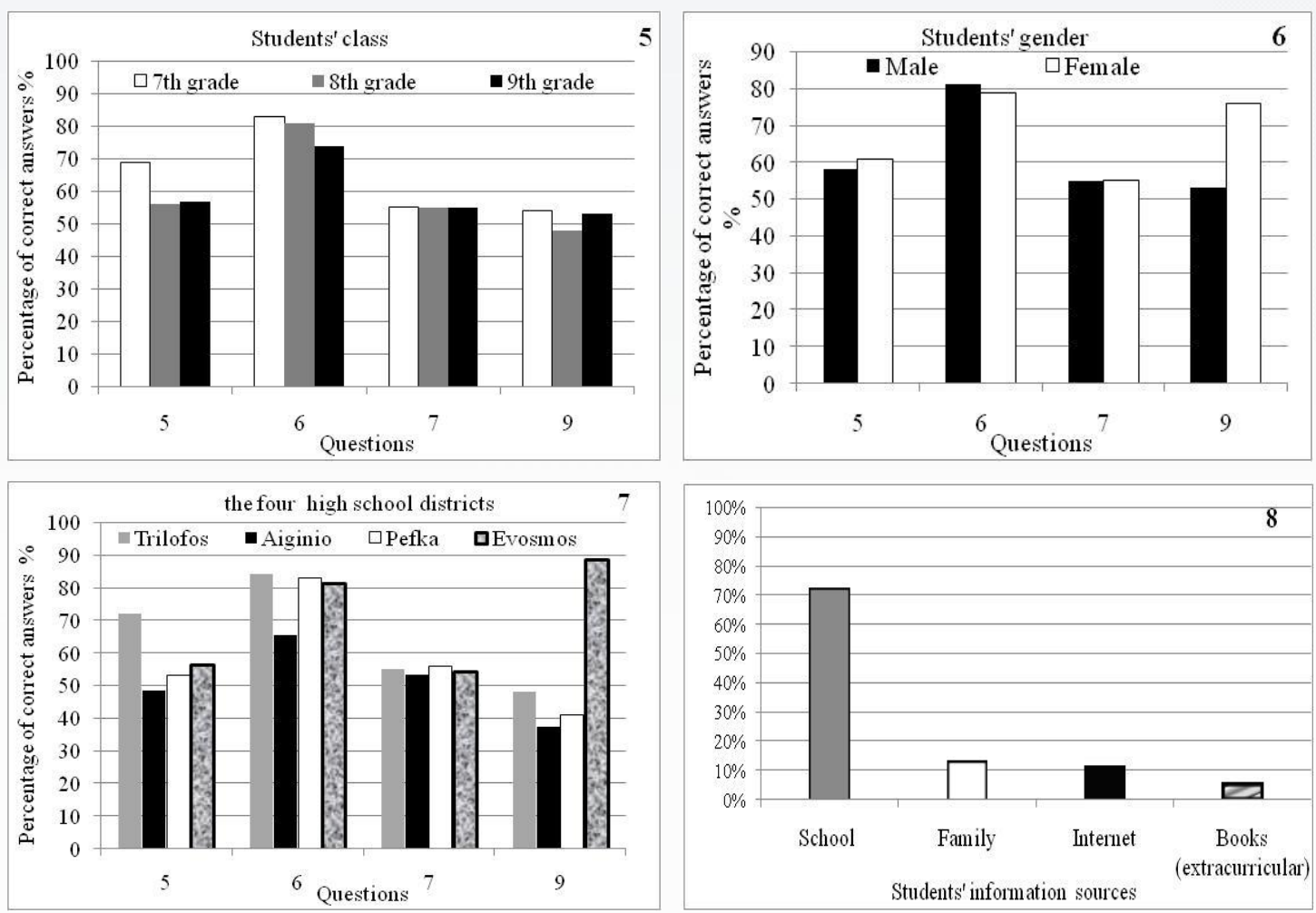

Figures 5-8. What are the students' actions and behavior in their daily life about the examined environmental issues in relation to their class grades (5), their gender (6) and their school district (7)? What the students" answers to question 13: "Where did you get information about greenhouse effect and global warming? (8). Bars depict percentage of students answered correctly to each of the following questions (q):

q-5: Do you wear an extra cloth (e.g. jacket) if the windows are closed, the heating is on and you still feel cold?

q-6: Do you keep heating off when you open the windows and doors to get fresh air, in your houses?

q-7: During winter, do you keep the house-temperature adjusted at around $20 \mathrm{oC}$ ?

q-9: Do you choose to come to school on foot or by bicycle?

\section{The Information Sources in the Construction of Knowledge and Awareness of the Students for the Studied Environmental Issues}

In question 13: "Where did you get information about greenhouse effect and global warming?", it is notable that most of the students $(71.6 \%)$, regardless their sociodemographic characteristics, mentioned that they got informed from the school (Figure 8). A low percentage (12.5\%) reports that they had been informed from their families, another $11.0 \%$ from the internet/ T.V , and only $4.9 \%$ from extracurricular books. The last finding dramatically shows the small impact of extracurricular books in informing students. Similar trends had already been earlier reported by Kilinc et al. (2008), who 
found that Turkish secondary students used the school as the main source of information about global warming (39\% on average), followed by television (24\%) and other sources (e.g. internet). On the contrary, in a survey conducted in schools in the Dodecanese islands (south-eastern Greece), ten years ago, a limited preference of school in relation to other information sources was found; the percentage of students got informed from the school was only $51.4 \%$, while T.V. has the lead in the information with a percentage of $84.2 \%$ (Liarakou et al., 2011).

\section{Students' Suggestions for Mitigation the Environmental Problems}

As far as the students' suggestions for the mitigation the studied environmental problems, (Table 2), it seems that the majority (78\%) suggests as the most important measures to be taken are the restriction of car traffic, the use of public transport, cycling, walking in case of short distances, and finally the use of electronic cars. The rest of the students $(16 \%)$ suggest the use of renewable energy sources, filters in the exhausts of cars and factory chimneys, instituting and enforcing relevant legislation, rising of ecological awareness, better environmental information and more environmental advocacy. In an earlier study of Pozapalidou (2011), more than $25 \%$ of Greek high school students proposed the use of renewable energy sources to reduce global warming. In the present study only a very small percentage ( $2 \%$ of the students) suggests the forests' conservation, the reforestations, and the reduction of logging and forest fires. This is not surprising, since such information is absolutely missing from the official school curriculum, despite the great importance of forests in mitigating climate change. In a bibliographic review of 16 international studies examining the perceptions of secondary school students, concluded that most of them believe that tackling global warming and climate change requires people to pollute the environment less and reduce carbon dioxide emissions, use less fossil fuel and plant more trees (Shepardson et al., 2009). In our study, the large percentage of students who raised the issue of transportation is remarkable. It seems to be the issue that touches them most, because it is directly connected with their everyday life, but it could be their outbreak due to very bad traffic conditions over the country.

Regarding the question 14: "Do you believe that your knowledge is sufficient to answer the questionnaire correctly?", 70\% of students answered YES, a fact that is in agreement with the results of the questionnaire itself and it may shows a very good selfknowledge of the students. In question 15: "Do you consider necessary the school provide you with appropriate knowledge on these environmental issues?", the majority of the students (85\%) answered YES. This high percentage shows that students heavily rely on the school, to get the information they need. This result in combination with the high percentage of the students mentioned that they got informed from the school (Figure 8) it indicates both the responsibility that each school should have as students' main source of environmental information, and the school's obligation to develop students' learning in a multifaceted way which simulates real conditions of the society and attracts students' interest. Similarly, previous studies highlighted the importance of school's role in acquiring knowledge and raising awareness of environmental issues. Daniel et al. (2004) found that two thirds (67\%) of the students (age 12-16) considered 
that school's education could play an effective role in reducing global warming. Ntanos et al. (2018) reported that around $80 \%$ of the students believe their schools should participate in recycling, while $2 / 3$ of the students consider that the school's environment affect and support their environmentally-based initiative and behavior.

Table 2

Students' Answers (N=600) To Question Q-10: Suggest A Solution, The Most Important, For The Mitigation Of Greenhouse Effect And Global Warming.'

\begin{tabular}{ll}
\hline \multicolumn{1}{c}{ Grouping students' answers } & $\begin{array}{c}\text { Percentage } \\
\text { of students } \\
\text { (\%) }\end{array}$ \\
\hline $\begin{array}{l}\text { Restricting car traffic / use of public transport / bicycle and walking for short } \\
\text { distances /electric cars }\end{array}$ & 77.6 \\
\hline Use of renewable energy sources & 4.2 \\
\hline $\begin{array}{l}\text { Use of filters in fuels, wheeled exhausts, factory chimneys and generally in } \\
\text { anything that emits a lot of gaseous pollutants, especially carbon dioxide }\end{array}$ & 5.4 \\
\hline $\begin{array}{l}\text { Reduction of carbon dioxide emissions from industries /factories in } \\
\text { accordance with legislation to be adopted on the basis of suggestions from } \\
\text { environmental organizations }\end{array}$ & 2.5 \\
\hline $\begin{array}{l}\text { Pollution reduction / environmental awareness / better environmental } \\
\text { information / more environmental advocacy }\end{array}$ & 5.9 \\
\hline Reducing heating intensity and wearing more clothes and less power wastage & 1.9 \\
\hline Conservation of forests / reforestations / reduction of logging and forest fires & 2.1 \\
\hline
\end{tabular}

\section{Conclusions}

Taking into account that the environmental knowledge provided by the Greek official public secondary school curriculum is very limited and fragmented, while the students' cognitive level on the terms greenhouse effect and global warming, what human actions cause these problems and their dangerous impacts, is high, the findings of this research are quite optimistic and lead us to recognize the usefulness of the method followed in the evaluation of the educational process.

The students' maturity seems to affect their cognitive level since it increases from the 7th to 9th grade students, depending on the question's nature. The students' gender and the school district do not influence their cognitive level on environmental issues, since no significant differences were detected either between males and females or urban, sub-urban and rural students, concerning the relevant environmental knowledge. The factor "parents' educational level" seems to play a critical role in students' knowledge. This percentage found lower in students that their parents received only primary education.

However, the majority of adolescents find it difficult to apply what they know about the examined environmental problems, in their daily life, and the vast majority of them appeared to share the same point of view for the mitigation of greenhouse effect and global warming: the restriction of car traffic, the use of public transport, cycling, walking on short distances, and finally the use of electronic cars. The above findings impose the need for reformation of the "natural sciences" curriculum, immediate and modern ways of teaching the "natural sciences", conducting environmental education programs, outdoor learning and teachers' education, in order to raise students' 
awareness and mobilize them with more ways to reduce their daily habits that harm the environment.

A large percentage of students point out that the school plays the key role in their information, and additionally they want the school to provide them with knowledge about such environmental issues. Thus, the results from this study highlight the great responsibility and important role of education in informing and raising awareness of students and consequently the tomorrow's citizens, and the duty of the Educational community to teach in a multifaceted way, that simulates the conditions of society and open the students to society.

The results of the present research can be utilized by experts and the Greek Educational community for the improvement of textbooks and the teaching of "natural sciences", so that the urgent environmental issues be included in curriculum content and taught more effectively. The school can manage to convince students that their daily attitude and habit will have medium- and long-term positive results in solving environmental problems with a global dimension.

\section{Acknowledgement}

We are very grateful to Geologist teacher MSc. A. Kalitsi, schools' Directors, Students, Parents and Teachers of $1^{\text {st }}$ high school of Trilofos, $2^{\text {nd }}$ high school of Evosmos, high school of Pefka and Aiginio, who assisted in conducting this research.

\section{References}

Ablak, S., Yeşiltaş, E. (2020). Secondary School Students' Awareness of Environmental Education Concepts. Review of International Geographical Education (RIGEO), 10 (3), 445-466.

Ampeliotis, K., Apostolopoulos, K., Georgitsogianni, E., Giannakoulia, M., Krokidi, E., Provatari, S. and Saiti, A. (2015). Home Economics of the 7th and 8th grade of high school, Student book. Diofantos.

Arslan, H.O., Cigdemoglu, C., Moseley, Ch. (2012). A Three-Tier Diagnostic Test to Assess Pre-Service Teachers' Misconceptions about Global Warming, Greenhouse Effect, Ozone Layer Depletion, and Acid Rain. International Journal of Science Education 34(11), 1667-1686.

Avramiotis, S., Angelopoulos, V., Kapelonis, G., Sinigalias, P., Spantidis, D., Trikaliti, G. and Filos, G. (2015). Chemistry 8th grade of high school, Student book. Diofantos

Bolaji, B.O., Huan, Z. (2013). Ozone depletion and global warming: Case for the use of natural refrigerant - a review. Renewable and Sustainable Energy Reviews 18, 49-54.

Bozdoğan, A.E. (2011). A Collection of Studies Conducted In Education About "Global Warming" Problem. Educational Sciences: Theory \& Practice 11(3), 1618-1624.

Boyes, E., Stanisstreet, M., Spiliotopoulou-Papantoniou, V. (1999). The ideas of Greek high School students about the "ozone layer". Science Education 83(6), 724-737.

Braun, T., Cottrell, R., Dierkes, P. (2018). Fostering changes in attitude, knowledge and behavior: demographic variation in environmental education effects. Environmental Education Research 24 (6), 899-920.

Carrier, S.J. (2010). Gender Differences in Attitudes toward Environmental Science. School Science and Mathematics 107 (7), 271-278. 
Coyle, K. (2004). Understanding environmental literacy in America: and making it a reality. National Environmental Education and Training Foundation, NEETF/Roper Report: Washington, DC.

Daniel, B., Stanisstreet, M., Boyes, E. (2004). How can we best reduce global warming? School students' ideas and misconceptions. International Journal of Environmental Studies 61(2), 211- 222.

Ekborg, M., Areskoug, A. M. (2006). How student teachers' understanding of the greenhouse effect develops during a teacher education program. NorDina 5, 17-29.

Eleftheriou, D., Kiachidis, K., Kalmintzis, G., Kalea, A., Bantasis, Ch. Koumadoraki, P., Spathara, M.E. Tsolaki, A., Tzampazidou, M. I., Gemitzi, A. (2018). Determination of annual and seasonal daytime and nighttime trends of MODIS LST over Greece-climate change implications. Science of the Total Environment 616-617, 937-947. https://doi.org/10.1016/j.scitotenv.2017.10.226.

Hansen, P.J.K. (2010). Knowledge about the Greenhouse Effect and the Effects of the Ozone Layer among Norwegian Pupils Finishing Compulsory Education in 1989, 1993, and 2005-What Now? International Journal of Science Education 32(3), 397-419.

Hines, J.M., Hungerford, H.R., Tomera, A.N., (1987). Analysis and synthesis of research on responsible environmental behavior: a meta-analysis. The Journal of Environmental Education 18 (2), 1-8.

Hyde, J.S., McKinleym, N.M. (1997). Gender differences in cognition. Results from MetaAnalyses. In Caplan P.J. Crawford M., Hyde J.S., Richardson J.T.E (Eds): Gender differences in human cognition, Chapter 2. (pp. 30-51). New York, Oxford University Press.

Intergovernmental Panel on Climate Change (IPCC) (2014). Climate change 2014: synthesis report. Contribution of working groups I, II and III to the fifth assessment report of the intergovernmental panel on climate change. Geneva: IPCC.

Jickling, B., Wals, E. J. (2008). Globalization and environmental education: looking beyond sustainable development. Journal of Curriculum Studies 40(1), 1-21.

Kilinç, A., Stanisstreet, M., Boyes, E. (2008). Turkish students' ideas about global warming. International Journal of Environmental \& Science Education, 3 (2), 89-98.

Koutsopoulos, K., Sotirakou, M., Tatsoglou, M. (2016). Geography in 6th grade primary school, Student book. Diofantos.

Lee, O., Lester, B.T., Ma, L., Lambert, J., Jean-Baptiste, M. (2007). Conceptions of the greenhouse effect and global warming among elementary students from diverse languages and cultures. Journal of Geoscience Education, 55(2), 117-125, DOI:10.5408/1089-9995-55.2.117.

Leslie, E, Kremer, P., Toumbourou, J.W., Williams, J.W. (2010). Gender differences in personal, social and environmental influences on active travel to and from school for Australian adolescents. Journal of Science and Medicine in Sport 13, 597-601.

Liarakou, G., Athanasiadis, I., Gavrilakis, C. (2011). What Greek secondary school students believe about climate change? International Journal of Environmental \& Science Education 6, 79-98.

Loughland, T., Reid, A., Walker, K., Petocz, P. (2003). Factors influencing young people's conceptions of environment. Environmental Education Research 9(1), 3-20.

Mavrikaki, E., Gouvra, M., Kampouri, A. (2016). Biology 8th grade of high school, Student book. Diofantos. 
Ganatsa, M.; Tsakaldimi, M.; Ganatsas, P. (2021).Factors affecting attitudes and behavior of Greek...

Mimikou, M.A., Baltas, E.A. (2013). Assessment of Climate Change Impacts in Greece: A General Overview. American Journal of Climate Change 3, 46-56.

National Research Council (1989). Ozone Depletion, Greenhouse Gases, and Climate Change. Washington, DC: The National Academies Press. https://doi.org/10.17226/1193.

Ntanos, S., Kyriakopoulos, G.L., Arabatzis, G., Palios, V., Chalikias, M. (2018). Environmental Behavior of Secondary Education Students: A Case Study at Central Greece. Sustainability 10, 1663. https://doi:10.3390/su10051663.

Nyberg, E., Castéra, J., Mc Ewen, B., Gericke, N., Clément, P. (2020). Teachers' and Student Teachers' Attitudes Towards Nature and the Environment-A Comparative Study Between Sweden and France. Scandinavian Journal of Educational Research, 64 (7), 1090-1104.

Olsson, D., Gericke, N. (2016). The adolescent dip in students' sustainability consciousnessImplications for education for sustainable development. The Journal of Environmental Education 47 (1), 35-51.

Olsson, D., Gerickea, N., Boeve-de Pauwa, J., Berglunda, T., Tzuchau Chang, T. (2019). Green schools in Taiwan - Effects on student sustainability consciousness. Global Environmental Change 54, 184-194.

Otto, S., Evans, G.W., Moon, M.J., Kaiser, F.G. (2019). The development of children's environmental attitude and behavior. Global Environmental Change 58, 101947.

Özmen, H., Karamustafaoğlu, O. (2006). Environmental consciousness and education relationship: Determination of how environment-based concepts are placed in Turkish science curricula. Asia-Pacific Forum on Science Learning and Teaching 7(2), 1-17.

Papageorgiou, G., Tsiropoulou, S. (2004). The impact of experiments on students" knowledge and explanation of significant aspects of the greenhouse effect. Journal of Science Education 5(1), 28-33.

Pavlopoulos, K., Galani, A. (2016). Geology - Geography of the 7th grade of high school, Student book. Diofantos.

Pozapalidou, S. (2011). The views of Secondary School students regarding global warming and climate change. Master of Science thesis, School of Humanities, University of the Aegean.

Sanchez-Llorens, S., Agullo-Torres, A., Del Campo-Gomis, F.J., Martinez-Poveda, A. (2019). Environmental consciousness differences between primary and secondary school students. Journal of Cleaner Production 227, 712-723.

Schreiner, C., Henriksen, E. K., Hansen, P. J. K. (2005). Cli $\neg$ mate education: Empowering today's youth to meet tomorrow's challenges. Studies in Science Education 41, 3-50.

Shepardson, D. P., Niyogi, D., Choi, S., Charusombat, U. (2009). Seventh grade students' conceptions of global warming and climate change. Environmental Education Research 15(5), 549- 570.

Stevenson, R.B. (2007). Schooling and environmental education: contradictions in purpose and practice. Environmental Education Research 13(2), 139-153.

Theodoropoulos, P., Papatheofanous, P. and Fillenia, S. (2016). Chemistry of the 9th grade of high school, Student book. Diofantos.

Tzimpoulas, N., Markou, M., Zioutis, V., Tzanetakis, G.N. (2019). A questionnaire-based survey for the evaluation of the knowledge level of primary school teachers on first-aid management of traumatic dental injuries in Athens, Greece. Dental Traumatology 00, 110 . 
Van der Schriek, T., Varotsos, K. V., Giannakopoulos, Ch., Founda, D. (2020). Projected Future Temporal Trends of Two Different Urban Heat Islands in Athens (Greece) under Three Climate Change Scenarios: A Statistical Approach. Atmosphere 11, 637; https://doi:10.3390/atmos11060637.

Varela, B., Sesto, V., García-Rodeja, I. (2020). An Investigation of Secondary Students' Mental Models of Climate Change and the Greenhouse Effect. Research in Science Education 50, 599-624.

Worsley, A., Skrzypiec, G. (1998). Environmental attitudes of senior secondary school students in South Australia. Global Environmental Change 8 (3), 209-225.

Yazdanparast, T., Salehpour, S., Masjedi, M.R., Seyedmehdi, S.M., Boyes, E., Stanisstreet, M., Attarchi, M. (2013). Global warming: knowledge and views of Iranian students. Acta Medica Iranica 51(3), 178-184.

Zsóka, A., Szerényi, Z. M., Széchy, A., Kocsis, T. (2013). Greening due to environmental education? Environmental knowledge, attitudes, consumer behavior and everyday proenvironmental activities of Hungarian high school and university students. Journal of Cleaner Production 48, 126-138..

\section{Biographical Statements}

Myrto GANATSA is an undergraduate student at the Aristotle University of Thessaloniki, Greece, interested in environmental education and actively participating at relevant studies.

Marianthi TSAKALDIMI Dr. Tsakaldimi belongs to Teaching \& Research staff of the Dept. of Forestry and Natural Environment of the Aristotle University of Thessaloniki, Greece. Her research interests are in the field of environmental science, ecosystem ecology, plant science, nature conservation.

Petros GANATSAS Dr. Prof. Ganatsas belongs to Teaching \& Research staff of the Dept. of Forestry and Natural Environment of the Aristotle University of Thessaloniki, Greece. His research interests are in the field of environmental science, ecosystem ecology, plant science, nature conservation. 